Doc. dr. Monika

Govekar-Okoliš

Asist. dr. Renata Kranjěec

Filozofska fakulteta Univerze $v$ Ljubljani

\title{
USPEŠNOST MENTORSTVA V IZOBRAŽEVANJU STAREJŠIH ODRASLIH
}

\section{POVZETEK}

Prispevek prinaša spoznanja o pomenu izobraževanja starejših odraslih za uspešno mentorstvo. Na kratko sta poudarjena pomen starejših odraslih in njihovega izobraževanja v sodobni družbi. Opredeljeno je mentorstvo kot oblika v izobraževanju starejših odraslih. Posebej pa smo se posvetili značilnostim, ki označujejo učinkovitega mentorja, kadar gre za skupinsko mentorstvo in v njem sodelujejo kot mentorji in kot mentoriranci starejše odrasle osebe. Izkazalo se je, da so mentorji kot vodje usmerjeni tako v doseganje ciljev kot tudi v vzdrževanje dobrih odnosov v skupini. Posebej se zavedajo tudi pomena stalnega lastnega profesionalnega razvoja ter evalvacije in samoevalvacije svojega mentorskega dela.

Ključne besede: starejši odrasli, izobraževanje, mentorstvo, uspešnost mentorstva, vodenje, učinkovit mentor, izobraževanje starejših odraslih

\section{SUCCESSFUL MENTORING IN EDUCATION OF OLDER ADULTS - ABSTRACT}

This paper presents the importance of education for older adults in the modern society and shows mentorship as one of its forms. It outlines the chracteristics of the effective mentor in the situation of group mentorship, where older adults participate both as mentors and as mentées. It shows that mentors as leaders strive at the achievement of goals as well as maintenance of good relationships in the group. They are also aware of the importance of their own continuous professional development and the evaluation and self-evaluation of their mentoring work.

Keywords: older adults, education, mentoring, successful mentoring, leadership, effective mentor, education of older adults

UDK: 374.7

\section{STAREJŠI ODRASLI IN IZOBRAŽEVANJE}

Starejši odrasli danes pomenijo zelo raznoliko skupino prebivalstva. To se kaže v njihovih individualnih razlikah od starosti, socialnega in ekonomskega položaja do zdravstvenih razlik. Menimo, da je z leti individualna posebnost posameznika čedalje bolj izrazita, in kot pravi Krajnčeva (1992: 15), je oseba vse bolj zvesta sama sebi ter vedno bolj odkrito izraža svoje bistvo. V populaciji starejših odraslih se kaže vedno več razlik med posamezniki, zato je populacijo starejših odraslih zelo težko opisati. Eni so sposobni pri isti starosti narediti več kot drugi, so boljšega zdravja, ekonomski in socialni status je raznolik in tudi pogledi na življenje in izobraževanje se razlikujejo.
Skupno vsem pa je, da živijo v sodobni družbi staranja, saj je delež starejših glede na vso družbo razmeroma velik in se z leti povečuje. Posledice starajoče se družbe imajo vpliv na razvoj gospodarstva, socialno politiko, na vsa področja družbenega življenja, tudi na področje izobraževanja odraslih.

Staranje prebivalstva pa dejansko ne pomeni grožnje obstoječi družbi, temveč prinaša spremembe, civilizacijski napredek. Omenjeno se nam potrjuje skozi obstoječe znanje starejših odraslih, njihove izkušnje in sposobnosti za sodelovanje ter delo na različnih področjih družbe. Zato je treba skupino starejših odraslih vključiti v družbo in ji z različnimi ukrepi omogočiti, da v njej dejavno sodeluje. Poleg tega naj poudarimo, da je treba tudi starejšim odraslim 
dati možnosti ne le za različna dela in dejavnosti, temveč tudi za nadaljnje izobraževanje. Ponuditi jim je treba znanja, ki jih potrebujejo za življenje in opravljanje različnih dejavnosti.

Danes starejši odrasli niso več na robu družbe. To nam dokazuje njihovo delo in vključevanje v različne dejavnosti, institucije, društva, krožke idr. Med njimi imajo prav gotovo pomembno vlogo Društvo za izobraževanje za tretje življenjsko obdobje, Univerza za tretje življenjsko obdobje, društva upokojencev idr., ki ponujajo starejšim odraslim številne možnosti za vključitev v skupine glede na interese po znanju in izkušnjah ali glede na njihovo sodelovanje pri vodenju skupin starejših odraslih. Za vse je potrebno izobraževanje, saj jim to omogoča izpolnitev želje po znanjih, za katere v življenju morda niso imeli ne časa, ne priložnosti in ne denarja, oziroma po znanjih, ki jih zahtevajo današnje hitre spremembe (npr. znati uporabljati računalnik). S tem ko starejšim odraslim dajemo možnost nadaljnjega izobraževanja, jim omogočamo, kot meni Fajdiga Severjeva (1993: 7), da ohranjajo telesno in duhovno vitalnost ter $\mathrm{s}$ tem bolj kakovostno in samostojno življenje. S tem pa dejansko starejši odrasli večjo vitalnost ponujajo celotni družbi. Starejši odrasli izhajajo iz svojih notranjih motivov, potreb in želja po samouresničevanju in večji kakovosti bivanja. Izbira nadaljnjega izobraževanja je pri starejši odrasli osebi dejansko odvisna od nje same, saj je preplet njene osebnosti, socialnega in poklicnega ozadja ter tudi vpliva prejšnjega izobraževanja in izkušnje $\mathrm{z}$ njim. To pomeni, da se bodo $\mathrm{v}$ nadaljnje izobraževanje raje vključevale tiste starejše odrasle osebe, ki so imele skozi življenje pozitivne izkušnje z izobraževanjem. Ne glede na to je izobraževanje za starejše odrasle pomembno, ker jim omogoča, da utrjujejo svoj družbeni položaj in se z različnimi dejavnostmi dejavno vključujejo v družbo. Pri tem naj poudarimo, kot pravi Findeisenova
(1999: 105-106), da se večina starejših odraslih izobražuje za lasten osebnostni razvoj in je njihovo izobraževanje veliko manj povezano $\mathrm{z}$ družbenim in ekonomskim razvojem. To pa pomeni, da moramo $\mathrm{v}$ današnji družbi spodbuditi starejše odrasle, da se bodo izobraževali ne le za lasten osebnostni razvoj, temveč da bodo svoja pridobljena znanja in izkušnje bolj povezali z razvojem družbe. Omenjeno potrjujejo tudi rezulati raziskave Kumpove in Jelenc Krašovčeve (2010: 8-9), ki poudarja pomen novega miselnega vzorca, to je dejavnega staranja, ki ga narekuje izobraževanje starejših odraslih. Dejavno staranje naj bi pomenilo razvijanje čim več potencialov starejših odraslih, njihovo vključevanje v ekonomsko, politično, družbeno in kulturno življenje v lokalni skupnosti pa tudi v širši družbi. Če izhajamo iz navedenega, je naloga vseh izobraževalcev starejših odraslih, da z vključitvijo starejših oseb v izobraževanje spodbudijo dejavno staranje in sodelovanje $\mathrm{v}$ družbi, saj bodo $\mathrm{s}$ tem starejšim odraslim dali možnost, da družbi še nekaj dajejo. S tem se vzpostavlja, kot opisuje Fajdiga Severjeva (1993: 14), nov daj-dam odnos, saj starejši odrasli niso tisti, ki le sprejemajo, temveč tudi dajejo. Menimo, da bomo tako zvišali stopnjo njihovega samouresničevanja in tudi kakovost bivanja.

Starejši odrasli se izobražujejo na različnih področjih, iščejo znanja o specifičnih življenjskih temah, potrebujejo znanja, ki jih takoj uporabijo v življenju, svojih dejavnostih, konjičkih, krožkih, društvih idr. Med takimi izobraževanji je tudi izobraževanje mentorjev starejših odraslih oseb, ki pridobivajo znanja s področja mentorstva $\mathrm{z}$ namenom, da bodo $v$ svojem delovanju lahko dobri mentorji drugim osebam, tako mlajšim kot starejšim. Glede na to, da starejši odrasli že imajo znanja in izkušnje z mentorstvom, je pričakovati, da so in bodo tudi v prihodnje dobri in uspešni mentorji. 


\section{MENTORSTVO KOT OBLIKA IZOBRAŽEVANIA}

V izobraževanju odraslih se danes prepletajo različne oblike izobraževanja, od individualnih do skupinskih in množičnih. Med individualne oblike izobraževanja štejemo samostojno izobraževanje oziroma samoizobraževanje odraslih, konzultacijo, e-izobraževanje, mentorstvo, svetovalno mentorstvo (coaching), tutorstvo ter vajeništvo oziroma druge oblike usposabljanja na delovnem mestu. Nekatere od teh oblike so lahko tudi skupinske (npr. konzultacija, mentorstvo, tutorstvo in e-izobraževanje). Med skupinske oblike izobraževanja odraslih štejemo še študijske krožke, tečaje in seminarje. Med množične oblike izobraževanja odraslih pa uvrščamo posvete, konference in sejme, prav tako pa sem sodi e-izobraževanje, kadar gre za učenje širše skupnosti, zlasti na področju nekaterih nujnih znanj (npr. preventivni zdravstveni ukrepi) (Govekar - Okoliš in Ličen, 2008: 67-69). Omenjene oblike so tudi sestavni del izobraževanja starejših odraslih. V prispevku se bomo posvetili mentorstvu kot eni od oblik izobraževanja starejših odraslih. Mentorstvo je ena od oblik izobraževanja, ki izhaja iz potreb starejše odrasle osebe, njenih izkušenj in potencialov ter pomaga posamezniku, da pride do zastavljenih ciljev. Ugotavljamo, da je lahko mentorstvo ena od zelo dobrodošlih in učinkovitih načinov dela, dejavnosti in izobraževanja pri starejših odraslih.

O tem, kaj je mentorstvo, danes obstaja veliko opredelitev. Razlike najdemo med posameznimi domačimi in tujimi avtorji. Na primer Krajnčeva (1979) opisuje, da je mentorstvo oblika vodenja, kjer gre za dolgotrajnejši proces medsebojnih stikov med mentorjem in posameznikom, ki je usmerjen na neko temo oziroma problem. Daloz (1986) vidi v procesu mentorstva način spodbujanja posamezni- ka, da osmisli življenjsko pot, tako da ga bo pripeljala do intelektualne rasti, sprememb in osebnostnega razvoja. Clutterbuck (1994) omenja mentorstvo kot vzajemen odnos med mentorjem in posameznikom, $\mathrm{v}$ katerem se oba vzajemno spoštujeta, prepoznavata lastno potrebo po osebnem razvoju ter imata razvito predstavo o tem, kam hočeta oba iti. Mentorstvo je proces, pravi Galbraith (1995), v katerem se združujejo mentorjeve in posameznikove izkušnje ter znanja. Med njima se začne graditi občutek zaupanja in skrbstva drug za drugega. Cohen (1995) pa poleg tega razlaga, da je mentorstvo dinamičen medosebni proces, znotraj katerega pridobivata izkušnje tako mentor kot mentoriranec. Billet (1999) mentorstvo povezuje $\mathrm{z}$ vodenim učenjem, kjer gre za interakcije in iskanja potencialnih virov znanja, pri čemer so pomembni elementi mentorjevo opazovanje posameznika pri izvajanju nalog, usmerjanje in dajanje neposrednih navodil ter posredovanje razumljivega znanja. Megginson in Clutterbuck (2005) poudarjata, da je mentorstvo dolgotrajen odnos, v katerem se cilji lahko spreminjajo in so oblikovani po željah posameznika. Bistvo mentorstva pa je v prepoznavanju in razvijanju potenciala posameznika, pri čemer je mentor tisti, ki posamezniku pomaga pridobiti vpogled ter $\mathrm{z}$ opazovanjem bolje razumeti in se zavedati lastnih izkušenj. Valenčič Zuljanova, Vogrinc, Bizjakova, Krištofova in Kalinova (2007) v svoji raziskavi omenjajo, da je za kakovostno mentorstvo pomemben profesionalen odnos med mentorjem in posameznikom, ki temelji na medsebojnem zaupanju in spoštovanju. Tudi Scandurova in Pellegrinijeva (2010) vidita mentorstvo kot diadni odnos, kot odnos med dvema, ki tesno sodelujeta. Podobno tudi Ramaswamijeva in Dreher (2010) navajata, da je bistvo mentorstva $\mathrm{v}$ pripravi posameznika za napredovanje. Za to so za mentorstvo pomembni elementi, kot so sprejemanje, vzor, potrjevanje, 
prijateljstvo, svetovanje, saj krepijo pozitivno samopodobo in pozitivno samovrednotenje posameznika ter mu dajejo občutek kompetentnosti, jasnijo njegovo identiteto ter povečujejo posameznikovo uspešnost. Govekar Okoliševa in Kranjčeceva (2010) menita, da je mentorstvo proces med mentorjem in posameznikom, v katerem se znanje in informacije prenašajo $\mathrm{z}$ bolj izkušene osebe na manj izkušeno. Vsako mentorstvo je drugačno. Menita, da obstaja toliko oblik mentorskega dela, kolikor je mentorjev. Zato mora mentor poznati različne oblike mentorstva, da jih lahko izbira in kombinira glede na posameznikove individualne značilnosti ali glede na skupino posameznikov, saj s tem dosega bolj učinkovito mentorstvo.

Pri vseh omenjenih avtorjih izvemo, da je mentorstvo načrtna pot, proces vodenja, svetovanja, vzajemen, dinamičen in diaden odnos med mentorjem in posameznikom. Gre za usmerjanje posameznika z nasveti, pojasnili, kjer mentor mentoriranca vodi, vzgaja, izobražuje, mu svetuje in razvija vedoželjnost ter ga spremlja na poti do zastavljenih ciljev. Posameznik naj bi $\mathrm{v}$ mentorskem odnosu gradil svojo osebnost, pridobil določena znanja in izkušnje, kar mu pomaga pri razvoju kariere, lastne identitete, pri doseganju osebnih ciljev. Mentorstvo je andragoška oblika dela, saj se vanj vključujejo posamezniki, ki za nadaljnje delovanje $\mathrm{v}$ nekem socialnem okolju potrebujejo nova in drugačna znanja in spretnosti. Pomembno je, kar spoznamo iz opredelitev mentorstva različnih avtorjev, da mentorstvo izhaja iz posameznikovih potreb, želja, interesov, izkušenj in predhodnih znanj ter v procesu tesnega sodelovanja z mentorjem odpira nove, zlasti neodkrite značilnosti osebnosti in podlage za posameznikovo nadaljnjo rast in razvoj. To pa mentor dosega z upoštevanjem posameznikov kot $\mathrm{z}$ ustrezno izbiro in kombinacijo oblik mentorstva.

\section{POMEN MENTORSTVA ZA IZOBRAŽEVANJE STAREJŠIH ODRASLIH}

Mentorstvo kot oblika andragoškega dela je pomembno tudi na področju dela in izobraževanja starejših odraslih. O mentorstvu se izobražujejo vsi tisti starejši odrasli, ki jih tematika zanima, morda zato, ker v življenju niso imeli priložnosti za mentoriranje ali pa so v življenju že bili mentorji ali ker v sodelovanju z različnimi institucijami, na primer z Univerzo za tretje življenjsko obdobje ali v okviru nekega društva vodijo skupino starejših odraslih in jih mento-

Mentorstvo je dinamičen medosebni proces. rirajo. Prav starejši odrasli so

lahko dobri mentorji, ker imajo veliko znanja in izkušenj, poleg tega pa veliko motivacije za učenje in pomoč drugim. Zavedajo se pomena mentorstva in jim to veliko pomeni, saj pri tem ne napreduje le njihov mentoriranec, temveč tudi sami kot mentorji. Večina mentorjev, kot kaže raziskava (Govekar - Okoliš in Kranjčec, 2010a), meni, da je mentorstvo organiziran in skrbno načrtovan proces. Pravijo, da gre za profesionalen, zaupen, spoštljiv odnos, v katerem mentor, bolj izkušen in vešč posameznik, prenaša svoje znanje, kompetence, izkušnje, veščine pa tudi prepričanja in vrednote na drugega posameznika, mentoriranca. Gre za vzajemen sodelovalen odnos, skupno odkrivanje in učenje, razvoj spretnosti in kompetenc. Ugotovimo, da mentorstvo pomaga odkrivati kritičnega in samostojnega ter ustvarjalnega posameznika, pomeni pa tudi pomoč posamezniku, njegovemu razvoju in boljši vključitvi v okolje. Lahko poudarimo, da je mentorstvo $v$ izobraževanju starejših odraslih pomembno za dejavno staranje, saj omogoča razvoj starejših odraslih, njihovo samouresničevanje in večjo kakovost bivanja ter večje sodelovanje v družbi. 
Mentorstvo starejšim odraslim se razlikuje od drugih mentorskih odnosov, ki nastanejo med mentorjem in posameznikom. V praksi izstopa raznolikost mentorstva, ki je pogojena $\mathrm{z}$ odnosi, ki se vzpostavijo v mentorstvu. Mentorstvo kot diadni odnos je za vsako starejšo odraslo osebo enkraten in neponovljiv. To pa, kot lahko ugotovimo, zato, ker odrasli že imajo določena znanja in izkušnje ter veliko svojih idej in motivov za različna dela, učenje in izobraževanje. Tako stopijo v medsebojne odnose mentorstva osebe, ki že imajo znanja in izkušnje, ki jih lahko povežejo z določenim izobraževanjem znotraj mentorskega procesa. Ponavadi gre za mentorstvo starejšim osebam, ki si želijo pridobiti znanje s področij, za katera skozi življenje niso imele ne časa ne možnosti. Poseben diadni odnos se kaže med mentorjem in mentorirancem, ki sta oba starejši in izkušeni osebi na vzgojno-izobraževalnem področju. Menimo, da je trdnost njunega sodelovalnega odnosa odvisna od njunih vlog v razvijajočih se vzgojnih odnosih. Tu mislimo na njuno nadaljnjo osebno rast. Mentoriranec in mentor morata biti odvisna drug od drugega, če hočeta doseči skupni cilj, da bo mentorstvo učinkovito.

Mentorstvo starejšim odraslim pa je odvisno tudi od tega, ali je formalno ali neformalno. Neformalno mentorstvo je, kot opisuje Colleyjeva (2003: 65), nenačrtovano, časovno neomejeno, pojavlja se bolj v domačih krogih in ima individualne cilje. Zanj so značilni tudi prostovoljci, ki delijo svoje znanje in izkušnje, iščejo prijateljstvo po lastni poti. Neformalno mentorstvo ima zato bolj izstopajočo visoko socialno intenziteto, je manj direktivno, vodeno in se povezuje s širšimi socialnimi vezmi v skupnosti. Ponavadi izvira iz lokalnih skupnosti. Čeprav je mentorstvo v večini primerov med starejšimi odraslimi znano kot neformalno, spontano, saj se dogaja v vsakdanjem življenju in v neformalnih vrstah iz- obraževanja, je vendarle večina mentorstev, kjer gre za izobraževanje starejših odraslih, tudi organizirana, načrtovana, kjer se upoštevajo potrebe vsakega posameznika, starejše odrasle osebe kot mentoriranca. Pravimo, da gre za formalno mentorstvo, za katerega je značilno, da mentorske odnose ureja organizacija. Bistveno za formalno mentorstvo je, kot meni Colleyjeva (2003:165), da je načrtovano, časovno omejeno, umeščeno v institucije in ima institucializirane cilje. Formalno mentorstvo ima zato bolj izstopajočo socialno distanco med udeležencema, bolj je osredotočeno na posameznika, odnos med mentorjem in mentorirancem pa je bolj direktiven, voden in se vzpostavi v procesu samem. Dejansko se formalno in neformalno mentorstvo starejšim odraslim razlikujeta že na ravni samega nastanka mentorstva, saj je prav od tega odvisno, kakšno bo mentorstvo, pa odnosi v njem, trajanje in način dela.

Mentorstvo starejšim odraslim je lahko individualno, tandemsko ali skupinsko. Bistvo individualnega mentorstva je sodelovalni odnos med mentorjem in mentorirancem, ki sta enakovredna, obojestransko sodelujeta, in kot pravi Krajnčeva (2012), je njuno sodelovanje usmerjeno v pomoč mentorirancu, da ta najde svojo pot do ciljev, ki so bili postavljeni. Pri individualnem mentorstvu je pomembna zaupna klima, kot razlaga Davisova (1994: 31), kar je prednost individualnega mentorstva. Gre za skupno delo dveh ljudi, ki si zaupata, med seboj razkrivata osebnostne poteze, komunicirata ter si na podlagi takšnega sodelovanja in dela lažje postavita in dosegata realne cilje.

Mentorstvo v tandemu oziroma dvojici starejših oseb je spet svojevrstno, saj se mentorski odnos in delo razširita na tri osebe, dva mentoriranca in enega mentorja. $\mathrm{V}$ tem odnosu je pomembna interakcija mentorja $\mathrm{z}$ vsakim 
posameznikom in hkrati z obema skupaj. Tak odnos se še razširi, kadar gre za skupinsko mentorstvo. Tu vstopa v odnose več starejših oseb, najmanj štiri, saj poleg mentorja sodelujejo najmanj trije starejši odrasli ali več. Tudi znotraj skupinskega mentorstva je pomembna interakcija med vsemi osebami v mentorskem odnosu. Posebnost pa je še v tem, da mora mentor skrbeti za ustrezno ozračje, da si posamezniki starejši odrasli med seboj lahko pomagajo, se učijo, sodelujejo, zaupajo, dobro komunicirajo, pri tej skupinski interakciji pa, kot naj poudarimo, odkrivajo svoj osebni slog, osebnostno rastejo in se nadaljnje razvijajo. Pri skupinskem mentorstvu mora mentor razviti spretnosti posameznika ob delovanju celotne skupine. Pomembna je skupina kot celota, ki je nad posameznikom. Cilji skupine so postavljeni pred cilje posameznika. Zato mora biti mentor še posebno pozoren, kako vodi interakcijo in kakšno ozračje mu uspe vzpostaviti med člani skupine. Pri tem pa je glavno, kot pravita Schoenfeld in Magnan (1994: 185), da posamezniki pridobijo nova znanja, Derrick in Dicksova (2005: 27) pa, da se morajo posamezniki tudi naučiti, kako dajati povratne informacije. Ne le to, starejši odrasli mentoriranci naj bi v skupini krepili altruizem in socialne tehnike, ki omogočajo oblikovanje posameznikove poti učenja, med njimi pa se stkejo različne vezi, zlasti medsebojna pomoč.

Za mentorstvo se mentorji in mentoriranci odločajo še pred začetkom mentorskega procesa, ko se mentorstvo načrtuje. Pri tem se seveda načrtujejo termin, delo in dejavnosti, cilji v mentorstvu, kar je odvisno od tega, ali se mentorira ena oseba, dve ali več. Pri vseh možnostih mentorstva pa moramo poudariti, da mora mentor upoštevati posameznikove osebnostne značilnosti, potrebe in že obstoječa znanja, saj na tej podlagi lažje sestavi načrt mentorstva in cilje. Oblikovanje in organiza- cija mentorstva zahtevata določen čas, pripravo in delo mentorja.

Mentorstvo kot oblika andragoškega dela je za starejše odrasle, kot smo že omenili, pomembno, saj omogoča, da se starejše osebe razvijajo ter pridobivajo znanja in izkušnje, ki jih nadalje uporabijo v življenju v skupnosti, v društvih, krožkih idr. Raziskave so pokazale, da so starejši odrasli zelo dobri mentorji. Omenimo raziskavo Starejši mentorji in rizična mladina (Freedman v Yes, You can, 1998: 12), ki ugotavlja, da imajo starejši odrasli mentorji nekatere izstopajoče značilnosti, kot sta empatija in potrpežljivost, ter nimajo težav $\mathrm{z}$ navezovanjem prijateljskih odnosov s posamezniki v mentorskem odnosu. Omenjena raziskava kaže, da so starejši odrasli dobri mentorji mladini, zlasti rizični mladini, saj jim ponujajo izkušnje, pomagajo reševati težave, razvijati komunikacijo idr. Prav gotovo bi bile zanimive raziskave, ki bi odkrivale, kakšni so odnosi med mentorjem in mentoriranci, kjer so vsi udeleženi starejše odrasle osebe. Podobno raziskavo o uspešnem mentorstvu bomo predstavili v nadaljevanju, kjer bomo podali opis mnenj, pogledov in izkušenj starejših odraslih mentorjev, ki so se udeležili izobraževanja za mentorje. Ti starejši odrasli so v življenju že bili mentorji, ali formalni ali neformalni, zdaj pa želijo deliti izkušnje mentorstva v skupinah starejših odraslih. Pred tem si poglejmo še nekaj stališč različnih avtorjev do uspešnega mentorstva.

\section{OD ČESA IE ODVISNA USPEŠNOST MENTORSTVA}

Vsak mentor ne glede na svojo starost, znanje in izkušnje si želi, da bi bil uspešen, in to ne glede na starost svojih mentorirancev. Uspešnost mentorstva je nasploh odvisna od različnih okoliščin. Od tega, ali gre za formalno 
ali neformalno mentorstvo, kot smo že omenili, ali gre za individualno mentorstvo, mentorstvo dvojici oseb ali skupini. Poleg tega smo zapisali, da je mentorstvo odvisno od interakcije vseh vključenih $\mathrm{v}$ mentorski proces, njihovega sodelovanja, zaupanja, klime, obstoječih znanj in izkušenj idr. Kaj pa je še pomembno za uspešnost mentorstva? Večina avtorjev meni, da je za uspešno mentorstvo pomemben mentorski odnos. Nekateri avtorji, npr. Cohen (1995), razlagajo, da se mentorski odnos deli na posamezne razvojne faze (zgodnjo, srednjo in pozno). To pomeni, da se mentorski odnos razvija postopoma.

Mentorski odnos med starejšima odraslima osebama, ki nastopata $\mathrm{v}$ vlogi mentorja in mentoriranca, ima svoj začetek, potek in konec. Na začetku se oblikuje zaradi določenih potreb posameznika starejše osebe in je usmerjen k vnaprej zastavljenim ciljem. Da je začetek mentorskega odnosa uspešen, pa sta pomembni, kot pravi Krajnčeva (2006: 33), bližina in medsebojna privlačnost mentorja in mentoriranca, kar omogoča in pospešuje učenje. Vedeti moramo, da se mentorski odnos vzpostavi šele v polju prijateljstva, medsebojnega zaupanja in spoštovanja. Šele tak stik omogoča, da se nadalje razvije mentorski odnos in da se potem nadaljuje $\mathrm{v}$ poteku mentorstva ter se tudi pričakovano uspešno konča. Spoznamo, da je mentorstvo starejšim odraslim razgiban sodelovalen proces, $v$ katerega so vključeni znanje, izkušnje, motivi in želje tako mentoriranca kot mentorja. Krajnčeva (2012: 23) poudarja, da mentorski odnos kot dinamičen socialni odnos pušča določene vtise in vpliva na vse udeležene $\mathrm{v}$ mentorskem odnosu. Prav vtisi in vplivi pa morajo biti koristni in pozitivni, da so lahko koristi mentorskega odnosa usmerjene k napredku vsakega mentoriranca in $\mathrm{k}$ nadaljnji pozitivni naravnanosti dela mentorja. To pomeni, da je mentorstvo uspešno.
Uspešnost mentorstva starejšim odraslim je odvisna od vseh posameznikov, ki so vključeni v mentorski odnos. Pri tem lahko še posebej obravnavamo mentorja, ki je ključna oseba, saj vodi, usmerja, pomaga, uči, svetuje, motivira idr., kot tudi vsakega posameznega starejšega udeleženca kot mentoriranca.

\section{ZNAČILNOSTI UČINKOVITEGA MENTORJA KOT VODJE V IZOBRAŽEVANJU STAREJŠIH ODRASLIH}

$\mathrm{V}$ raziskavi je sodelovalo 41 starejših odraslih mentorjev z izkušnjami skupinskega mentorstva starejšim odraslim osebam. Mentorji so bili udeleženci izobraževanj za mentorstvo starejšim odraslim osebam na Univerzi za tretje življenjsko obdobje v februarju in aprilu 2013. Njihova mnenja o učinkovitosti mentorja smo pridobili $\mathrm{v}$ razpravah, ki so potekale v manjših skupinah (praviloma po trije v skupini). Pregled njihovih mnenj o učinkovitosti mentorja pokaže, da v skladu z vedenjskim pristopom $\mathrm{k}$ vodenju poudarjajo dve glavni usmeritvi mentorjev kot vodij, to sta usmerjenost $v$ doseganje ciljev in usmerjenost $v$ medosebne odnose (Slika 1). V 50. letih prejšnjega stoletja se je namreč pozornost $\mathrm{V}$ raziskavah od lastnosti vodij preusmerila $\mathrm{k}$ njihovemu vedenju. Vedenjski pristop ugotavlja, kaj vodje dejansko počnejo pri delu, in raziskuje razmerje med vodstvenim vedenjem in vodstveno učinkovitostjo.

Skupini raziskovalcev, ena na državni univerzi v Ohiu in druga na univerzi v Michiganu, sta izvedli obsežni projektni nalogi o vedenju vodij. Skupini sta delali neodvisno in sta se naloge lotili z različnih vidikov. 
Skupina v Ohiu je poskušala ugotoviti najpomembnejše lastnosti vodij, in sicer tako, da je spraševala sodelavce o značilnostih njihovih vodij, manj pa tudi vodje same o njihovem značilnem vedenju. Na podlagi skoraj dva tisoč vprašanj, ki so jih oblikovali na začetku, so odkrili deset dimenzij vedenja vodij. Izkazalo se je, da v ozadju teh desetih dimenzij ležita dve bolj splošni dimenziji, ki sta se dosledno pojavljali tudi $\mathrm{v}$ nadaljnjih raziskavah in jih je Fleishman (Arnold, Cooper in Robertson, 1995; Webster in Starbuck, 1988) opisal kot:

- usmerjenost k upoštevanju sodelavcev, tj. stopnja, do katere vodja izkazuje zaupanje do sodelavcev, ki jih vodi, spoštuje njihove ideje in upošteva njihova čustva;

- usmerjenost $\mathrm{k}$ strukturiranju dela, tj. stopnja, do katere vodja določa in strukturira lastno vlogo in vlogo sodelavcev pri doseganju ciljev. Aktivnosti vodje narekujejo aktivnosti skupine, tako da vodja načrtuje delo, razporeja, daje informacije, ocenjuje oziroma presoja in preizkuša nove ideje.

Skupina v Michiganu pa je začela z razvrščanjem vodij $\mathrm{v}$ učinkovite in neučinkovite ter poskušala ugotoviti vedenja, ki ti dve skupini razlikujejo. Izkazalo se je, da je učinkovite vodje od neučinkovitih mogoče razlikovati po tem, da prvi skrbijo za sodelavce, ki jih vodijo, drugi pa skrbijo samo za izvajanje nalog. Ti dve dimenziji so poimenovali (Northouse, 2004; Arnold idr., 1995):

- usmerjenost na ljudi in

- usmerjenost na produktivnost.

Ugotovitev je zelo podobna izsledkom skupine v Ohiu, ki razlikuje usmerjenost vodij $\mathrm{k}$ upoštevanju sodelavcev in usmerjenost $\mathrm{k}$ strukturiranju dela. Na prvi pogled bi lahko rekli, da je usmerjenost $\mathrm{k}$ sodelavcem dobra in usmerjenost $\mathrm{k}$ strukturiranju nalog slaba, če je ne dopolnjuje usmerjenost $\mathrm{k}$ sodelavcem.

Izsledki mnogih raziskav kažejo, da je v večini situacij nujna določena mera upoštevanja sodelavcev, če hočemo, da so odnosi med vodjo in njegovimi sodelavci zadovoljivi. Kadar merimo učinkovitost skupine, pa ni vedno jasno, ali je upoštevanje sodelavcev oziroma strukturiranje dela dobro, slabo ali pa brez vpliva (Arnold idr., 1995).

Nekatere raziskave so potrdile, da sta ti dve dimenziji univerzalni. Med najbolj znanimi je raziskava Smitha, Misumia, Tayeba, Petersona in Bonda iz 80. let (Arnold idr., 1995; Wang, 1991), ki je zajela podatke iz Velike Britanije, Združenih držav Amerike, Japonske in Hongkonga ter odkrila dimenziji:

- usmerjenost v vzdrževanje skupine, odnosov v skupini,

- usmerjenost v doseganje ciljev.

Navedeni dimenziji približno ustrezata dimenzijama, ki jih je odkrila skupina v Ohiu, torej usmerjenosti k upoštevanju sodelavcev in usmerjenosti k strukturiranju dela. Odkritje obeh ekvivalentnih dimenzij v mednarodnih razsežnostih kaže na njun obstoj v različnih kulturah.

Obe dimenziji vodenja pri mentorstvu so $\mathrm{v}$ našem primeru $\mathrm{v}$ ospredje postavili tudi starejši odrasli mentorji, ki imajo izkušnje z mentorstvom skupinam starejših odraslih. Pregled njihovih mnenj je prikazan v Sliki 1.

z Slike 1 je razvidno, da se usmerjenost $\boldsymbol{v}$ doseganje ciljev pri mentorju kot vodji kaže kot načrtovanje in organizacija dela. Za mentorje starejšim odraslim je pomembno, da je delo 


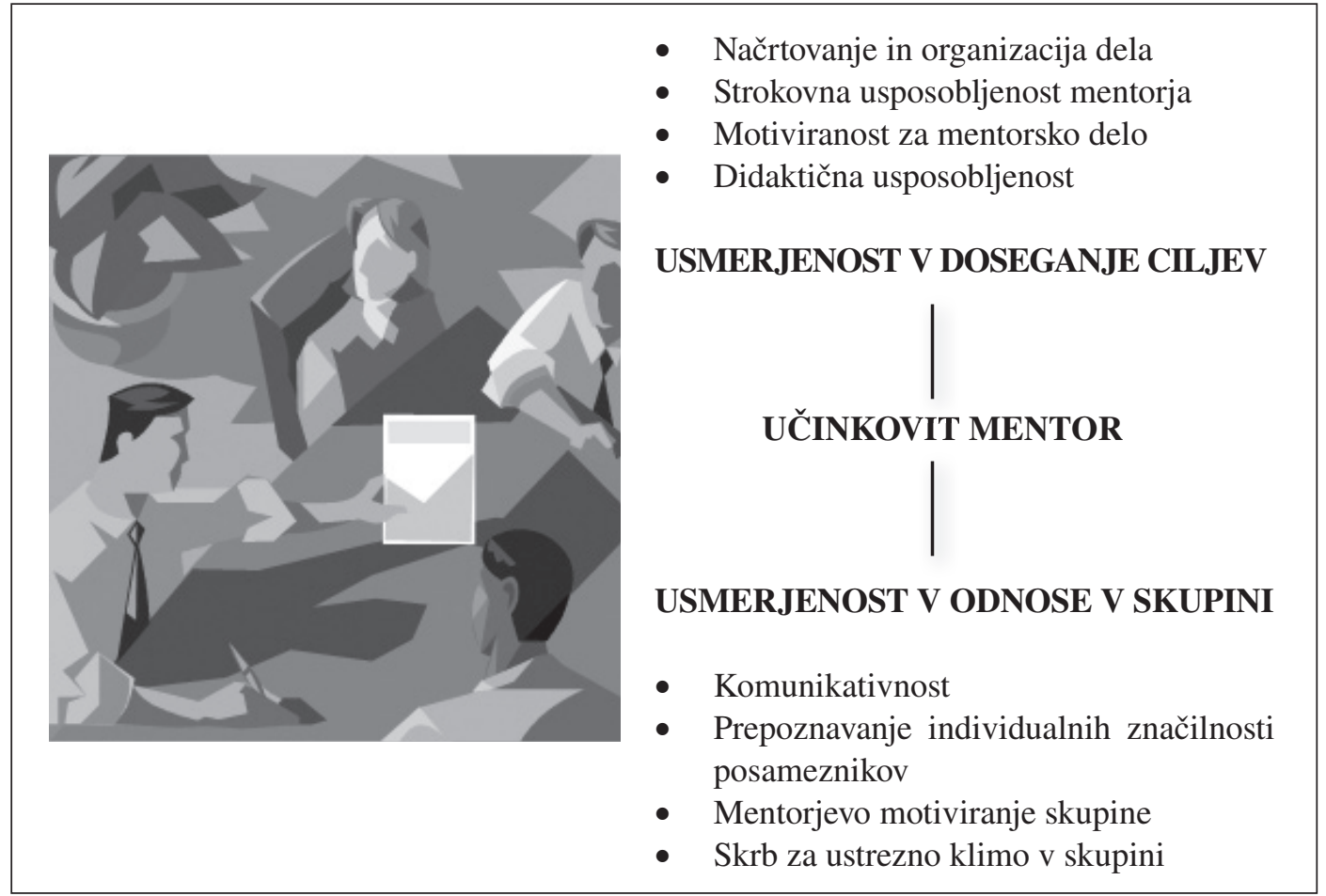

Slika 1: Vedenjske značilnosti učinkovitega mentorja v izobraževanju starejših odraslih

načrtovano tako, da ga je možno individualno prilagajati mentorirancem v skupini. Mentor naj zna naloge porazdeliti in njihovo izvajanje koordinirati ter skrbeti za točnost pri izvajanju programa mentorstva. Pozoren naj bo na posameznikov sprotni napredek in ga $\mathrm{v}$ skladu s tem usmerja.

Naslednji pomembni dejavnik pri doseganju ciljev je, da je mentor strokovno ustrezno usposobljen. Starejši odrasli pričakujejo široko strokovno znanje mentorja kot tudi njegovo izkušenost, ki se naj izkazujeta v njegovem izvajanju mentorstva v skupini. Prav tako naj zna vključiti znanja in izkušnje mentorirancev.

Glede motiviranosti mentorja za svoje delo starejši odrasli z izkušnjami z mentorstvom skupinam starejših odraslih menijo, da naj bo ta notranja. Pomembno je, da je mentor samoiniciativen, delaven in da uživa ob svojem delu. Plačilo njegovega dela na primer kot zunanja motivacija naj bo vsekakor drugotnega pomena.

V izobraževanju odraslih je ključna tudi didaktična usposobljenost mentorja. Mentor naj ne bo monoton, znanje in predvidene teme naj podaja na zanimiv in dinamičen način in to podajanje prilagaja skupini kot celoti kot tudi posameznikom v njej. Obvlada naj različne načine poučevanja. Vsekakor naj ne bo slabo pripravljen za izvedbo izobraževanja. Pomembno je tudi, da je retorično spreten.

Usmerjenost mentorja $v$ odnose $v$ skupini se kaže na različne načine. Eden od njih je gotovo komunikativnost mentorja. Mentor naj bo dostopen, naj ne komunicira predvsem enosmerno, ampak naj vključuje vse člane skupine. Pozoren naj bo na to, da ne bodo v komunikacijo vključeni le nekateri, drugi pa se bodo počutili odrinjene. 
Še posebej mentorji starejšim odraslim omenjajo vlogo prepoznavanja individualnih značilnosti posameznikov. Od mentorja pričakujejo, da jih bo prepoznal kot posameznike, jim znal prisluhniti, prepoznati njihove potrebe ter tudi njihove značajske in druge značilnosti. Od njega pričakujejo nasvete.

Pomembno je tudi mentorjevo motiviranje skupine, tako posameznikov v njej kot skupine $\mathrm{v}$ celoti. Od njega pričakujejo, da bo prepoznal, kdaj pričakujejo opogumljanje in spodbujanje.

Za uspešnost skupinskega mentorstva je ključna tudi skrb za ustrezno klimo $v$ skupini. Mentor naj zna ustrezno pristopiti k skupini in naj jo povezuje. Biti mora čustveno stabilen in sposoben zaznati čustveno doživljanje članov skupine. Pozoren naj bo na morebitne konflikte med člani skupine ter poskrbi za njihovo konstruktivno reševanje. Tako mentor kot člani skupine naj vzdržujejo medsebojno spoštljiv odnos $\mathrm{v}$ prijaznem in sproščenem vzdušju. Pomembno je tudi, da zna mentor dajati konstruktivne povratne informacije ter da je nepristranski in odgovoren.

Skupina starejših odraslih, ki so bili mentorji skupinam starejših odraslih, se je posebej zavedala pomena evalvacije mentorskega dela kot tudi samoevalvacije svojega dela. Poudarili so pomen profesionalnosti mentorja in njegove skrbi za lasten stalen profesionalni razvoj in napredek.

Prednosti skupinskega mentorskega modela Tancig (2010) vidi v možnostih udeležencev, da se srečujejo in reflektirajo svoj napredek, kar spodbuja večjo motivacijo in dodatno podporo ter ustvarja priložnosti, da se mentorji in mentorirani učijo drug od drugega. S tem pa se lažje dosegajo zastavljeni cilji in je uspešnost mentorstva večja.

\section{SKLEPNE MISLI}

V današnji družbi moramo poskrbeti, da se lahko starejši odrasli dejavno vključujejo v različne oblike izobraževanja. Ena izmed teh je tudi mentorstvo, ki jim daje možnost, da v mentorskem odnosu pridobivajo znanja in izkušnje ne glede na to, ali so mentorji ali mentoriranci. S tem ko starejšim odraslim dajemo možnost nadaljnjega izobraževanja, jim tudi omogočamo, da ohranjajo telesno in duhovno vitalnost ter s tem bolj kakovostno in samostojno življenje. S tem jih spodbujamo, da so dejavni, da sodelujejo in družbi še vedno nekaj dajejo. Po tej poti bomo uresničevali koncept dejavnega staranja pri starejših odraslih pri nas.

Starejši odrasli že imajo znanja in izkušnje ter se za izobraževanje odločajo glede na svoj interes, potrebo ali druge razloge. Mentorstvo kot oblika izobraževanja starejših odraslih je zelo pomembno, saj starejšim omogoča ne le sodelovanje, temveč tudi izobraževanje in osebnostno rast. To velja, če prevzamejo vlogo mentorja ali pa če so v vlogi mentoriranca. Njihov odnos je specifičen glede na njihovo starost, že pridobljeno znanje in izkušnje, njihove potrebe in motive ter želje nekaj narediti, doseči in osebnostno rasti. Pomembno je, da je vsak posameznik v mentorskem odnosu sprejet kot individuum in hkrati kot del dvojice mentor-mentoriranec ali skupine mentor-mentoriranci. Prav ta sprejetost v mentorstvu odpira možnosti za sodelovanje, medsebojno pomoč, svetovanje, učenje in izobraževanje ter nadaljnjo osebnostno rast. Medsebojna odvisnost posameznikov v mentorskem odnosu je pravzaprav pogoj za to, da dosežemo skupni cilj, kar pomeni, da je mentorstvo učinkovito. Pri tem niti ni toliko pomembno, ali je mentorstvo formalno ali neformalno, ali poteka med mentorjem in posameznikom, dvojico mentorirancev ali skupino teh. Pomembno je, 
kot lahko razberemo iz mnenj različnih avtorjev in njihovih raziskav, da je mentorstvo učinkovito, da se v njem dosežejo cilji, ki so lahko bolj izobraževalni ali bolj vzgojni, pomembno je, da napreduje vsak posameznik v mentorskem odnosu. Tu mislimo na mentoriranca in tudi na mentorja. Takrat, ko bosta $\mathrm{v}$ mentorstvu vzpostavila dober in prijateljski odnos, medsebojno spoštovanje, sodelovanje, napredovanje $\mathrm{v}$ znanju in izkušnjah idr., bo mentorstvo uspešno. Pri doseganju uspešnega mentorstva med starejšimi odraslimi osebami je torej pomemben prispevek mentorja kot tudi prispevek vsakega udeleženca mentoriranca. Mentorjeva vloga je, da poskrbi za ustrezen mentorski odnos, ki se skozi mentorstvo sproti razvija. Mentor je tista ključna oseba, ki vodi, usmerja, pomaga, uči, svetuje, motivira idr. vsakega posameznega starejšega odraslega kot mentoriranca. Prav vloga mentorja se pogosto postavlja v ospredje kot ključna za razvoj dobrih odnosov v mentorstvu in sploh, da je uspešnost mentorstva odvisna prav od mentorja.

Pregled mnenj starejših odraslih mentorjev o učinkovitosti mentorja kaže na to, da vidijo ti mentorja v izobraževanju starejših odraslih oseb kot vodjo, ki naj bo usmerjen v doseganje ciljev, prav tako pa v njem vidijo tistega, ki skrbi za medsebojne odnose v skupini. Pri zagotavljanju doseganja ciljev skupine so izstopajoči dejavniki načrtovanje in organizacija dela, strokovna usposobljenost mentorja, njegova motiviranost za mentorsko delo ter didaktična usposobljenost, pri skrbi za medsebojne odnose v skupini pa njegova komunikativnost, prepoznavanje individualnih značilnosti posameznikov, njegovo motiviranje skupine in skrb za ustrezno klimo v skupini. Še posebej se starejši odrasli mentorji zavedajo pomembnosti evalvacije mentorskega dela, svoje lastne evalvacije in potrebe po stalnem profesionalnem razvoju. Zato je treba izobraževanja starejših odraslih o mentorstvu podpirati, saj so starejši odrasli glede na svoje izkušnje in znanja lahko pomemben vir razvoja družbe samousmerjajočih se ljudi, ki se vseživljensko izobražujejo.

\section{LITERATURA IN VIRI}

Arnold, J.; Cooper, C. L.; Robertson, I. T. (1995). Work Psychology: Understanding human behavior in the workplace. London: Pitman publishing.

Billett, S. (1999). Guided learning at work. V: Boud, D.; J. Garrick. Understanding Learning at Work. London and New York.

Clutterbuck, D. (1994). Everyone needs a mentor: fostering talent at work. London: Institute of Personnel and Development.

Cohen, N. H. (1995). Mentoring Adult Learners. Malabar: Kreiger Publising Company.

Colley, H. (2003). Mentoring for Social Inclusion. A critical approach to nurturing mentor relationships.. London, New York: RoutledgeFalmer.

Daloz, L. A. (1986). Effective teaching and mentoring: realizing the tranformational power of adult learning experiences. San Francisco: Jossey-Bass.

Davis, M. (1994). A Tutor's Guide to Open Learning. London: Macmillan Magazines.

Derrick, J., in Dicks, J. (2005). Teaching Practise and Mentoring. Leicester: Niace.

Fajdiga Sever, P. (1993). Slovenska univerza za tretje življenjsko obdobje. Ljubljana: Slovenska univerza za tretje življenjsko obdobje pri Andragoškem društvu Slovenije.

Findeisen, D. (1999). Izobraževanje odraslih v njihovih poznejših letih (doktorska disertacija). Ljubljana: Univerza v Ljubljani, Filozofska fakulteta.

Galbraith, M. W.; Cohen, N. H. (1995). Mentoring: new strategies and challenges. San Francisco: Jossey-Bass.

Govekar - Okoliš, M.; Kranjčec, R. (2010). Izobraževanje mentorjev za praktično usposabljanje študentov po bolonjskih študijskih programih v podjetjih/zavodih. Ljubljana: Filozofska fakulteta, 
Center za pedagoško izobraževanje, Znanstvena založba Filozofske fakultete.

Govekar - Okoliš, M.; Kranjčec, R. (2010a). Pogledi mentorjev na praktično usposabljanje študentov $v$ delovnih organizacijah. Ljubljana: Filozofska fakulteta, Center za pedagoško izobraževanje, Znanstvena založba Filozofske fakultete.

Govekar - Okoliš, M.; Ličen, N. (2008). Poglavja iz andragogike. Ljubljana: Znanstvena založba Filozofske fakultete, Oddelek za pedagogiko in andragogiko.

Krajnc, A. (1979). Metode izobraževanja odraslih: andragoška didaktika. Ljubljana: Delavska enotnost.

Krajnc, A. (1992). Kako smo snovali Slovensko univerzo za tretje življenjsko obdobje. Ljubljana: Slovenska univerza za tretje življenjsko obdobje.

Krajnc, A. (2006). Kdo so bili moji mentorji? Kdo mi je lahko mentor? Andragoška spoznanja, 4: 31-39.

Krajnc, A. (2012). Individualizacija izobraževanja vodi v mentorstvo. Gibanje 'Znaš, nauči drugega'. Andragoška spoznanja, 2: 19-30.

Kump, S.; Jelenc Krašovec, S. (2010). Prestari za učenje?: vzorci izobraževanja in učenja starejših. Ljubljana: Pedagoški inštitut, Znanstvena založba Filozofske fakultete.

Megginson, D.; Clutterbuck (2005). Techniques for Coaching and Mentoring. Oxford, Burlington: Elsevier.

Northouse, P. G. (2004). Leadership: Teory and practice. Thousand Oaks: Sage Publications.

Ramaswami, A.; Dreher, G. F. (2010). The Benefits Associated with Workplace Mentoring Relationships. V: T. D. Allen in L.T. Aby (ur.), The Blackwell Handbook of Mentoring. West Sussex.

Scandura, T. A.; Pellegrini, E. K. (2010). Workplace Mentoring: Theoretical Approaches and Methodological Issues. V: T. D. Allen in L. T. Aby (ur.). The Blackwell Handbook of Mentoring. West Sussex.

Schoenfeld, A. C.; Magnan, R. (1994). Mentor in a Manual. Climbing the academic ladder to tenure. Madison: Atwood publishing.
Tancig, S. (2010). Raziskave, pristopi in modeli supervizije (mentorstva) podiplomskega študija. V: A. Kobolt (ur.). Supervizija in koučing. Ljubljana: Univerza v Ljubljani, Pedagoška fakulteta, Zavod Republike Slovenije za šolstvo.

Valenčič Zuljan, M. (ur.) (2007). Izzivi mentorstva. Ljubljana: Pedagoška fakulteta Univerze v Ljubljani.

Wang, Z.-M. (1991). Recent Developments in Industrial in Organizational Psychology in people's Republic of China. International review of industrial and organizational psychology, 6: 7-11.

Webster, J.; Starbuck, W. H. (1988). Theory Building in Industrial and Organizational Psychology. International review of industrial and organizational psychology, 3: 130.

Yes, You can. A guide for establishing mentor programs. (1998). Washington: U. S. Department of Education. Dostopno na: http://www2.ed.gov/ PDFDocs/yyc.pdf (3. 8. 2013). 